Pteridines

Vol. 10, 1999, pp. 213-216

\title{
Insulin Stimulates Tetrahydrobiopterin Synthesis in Mouse Brain Microvascular Endothelial Cells
}

\author{
Masakazu Ishii ${ }^{1}$, Shunichi Shimizu ${ }^{2}$, Tsutomu Nagai ${ }^{1}$, Yuji Kiuchi ${ }^{2}$ and Toshinori Yamamoto ${ }^{1, \$}$ \\ Departments of ${ }^{1}$ Clinical Pharmacy and ${ }^{2}$ Pathophysiology, School of Pharmaceutical Sciences, Showa \\ University, 1-5-8 Hatanodai, Shinagawa-ku, Tokyo 142-8555, Japan
}

, Received November 1, 1999)

\begin{abstract}
Summary
We examined the effects of insulin on tetrahydrobiopterin (BH4) synthesis in mouse brain microvascular endothelial cells (MBMECs). Treatment of MBMECs with insulin increased the intracellular BH4 content in a time- and concentration-dependent manner. The insulin-induced increase in BH4 content was inhibited by treatment with 2,4-diamino-6-hydroxypyrimidine, a selective inhibitor of GTP cyclohydrolase I, and Nacetylserotonin, a selective inhibitor of sepiapterin reductase. These findings indicate that insulin stimulates BH4 synthesis in MBMECs through a de novo synthetic pathway of BH4.
\end{abstract}

Key words: Tetrahydrobiopterin, Insulin, Endothelial cell

\section{Introduction}

Insulin is produced and secreted from the pancreas, and regulates carbohydrate, protein and fat metabolism in mammals. Moreover, insulin has been shown to stimulate the production of nitric oxide (NO) in endothelial cells, and to elicit vasodilation (1-3). Verma et al. (4) indicated that insulin-induced vasodilation is attenuated by inhibition of $\mathrm{BH} 4$ synthesis. $\mathrm{BH} 4$ is known to be an essential cofactor of NO synthase, and regulates NO synthase function $(5,6)$. Therefore, they speculated that insulin may regulate NO production by increasing $\mathrm{BH} 4$ synthesis in endothelial cells is still not determined. As another

\$Corresponding author: Toshinori Yamamoto, Ph. D. Department of Clinical Pharmacy School of Pharmaceutical Sciences Showa University Shinagawa-ku, Tokno 142-8555, Japan. Fax: +81-3-3784-3838, e-mail: vamagen@pharm.showa-u.ac.jp * Parts of the work were presented at the $6^{\text {th }}$ Meeting of Cytokine and Neopterin held on July 24, in Tokyo, Japan function, insulin is known to have a protective effect against ischemic injury in various tissues including brain and heart $(7,8)$. We recently reported that $\mathrm{BH} 4$ has a protective effect against vascular endothelial cell injury induced by $\mathrm{H}_{2} \mathrm{O}_{2}, \mathrm{NO}$ and a combination of superoxide and $\mathrm{NO}$, which are implicated in a development of reperfusion injury following ischemia (914). More recently, in vivo, we showed that $\mathrm{BH} 4$ attenuates gastric ischemia-reperfusion injury (15). The protection mechanisms of $\mathrm{BH} 4$ are likely to involve the scavenging activity of reactive oxygen species and antioxidative activity $(10,16)$. If insulin stimulates BH4 synthesis in endothelial cells, it is possible that the increase in $\mathrm{BH} 4$ content may be involved in the protection mechanisms of insulin against ischemic injury. In this study, we examined whether isulin increases in BH4 synthesis in MBMECs.

\section{Materials and Methods}

Cell culture 
MBMECs were obtained from Toyobo Co. (Tokyo, Japan). Cells were cultured in Dulbecco's modified Eagle's medium containing $10 \%$ FBS, $100 \mathrm{U} / \mathrm{ml}$ penicillin and $100 \mu \mathrm{g} / \mathrm{ml}$ streptomycin.

\section{Measurement of intracellular biopterin content}

Confluent endothelial cells in 6-well plates were washed 2 times with physiological saline solution (PSS, pH 7.4) containing $118.5 \mathrm{mM} \mathrm{NaCl}, 4.74 \mathrm{mM}$ $\mathrm{KCl}, 2.5 \mathrm{mM} \mathrm{CaCl}, 1.18 \mathrm{mM} \mathrm{MgSO}, 1.18 \mathrm{mM}$ $\mathrm{KH}_{2} \mathrm{PO}_{4}, 2.5 \mathrm{mM} \mathrm{NaHCO}, 11 \mathrm{mM}$ glucose and 10 $\mathrm{mM}$ N-2-hydroxyethylpiperazine-N'-2-ethanesulfonic acid, and incubated with insulin at $37^{\circ} \mathrm{C}$ in $2 \mathrm{ml}$ PSS. After treatment with insulin for various periods $(0-24 \mathrm{~h})$, intracellular $\mathrm{BH} 4$ was released by addition of $10 \%$ trichloroacetic acid on ice for 30 min. BH4 content was measured by oxidation in acid conditions as biopterin, with reversed-phase high performance liquid chromatography with fluorometric detection, as previously described (9).

\section{Materials}

Insulin (from bovine pancreas) and $\mathrm{N}$-acetylserotonin (NAS) were obtained from Sigma Chemical Co. (St. Louis, MO, U.S.A.). 2,4-Diamino-6-hydroxypyrimidine (DAHP) was obtained from Aldrich Chemical Co. (Tokyo, Japan). All other reagents were of the highest grade commercially available.

\section{Statistical analysis}

Data are presented as means \pm S.E.M. of $\mathrm{n}$ obser-

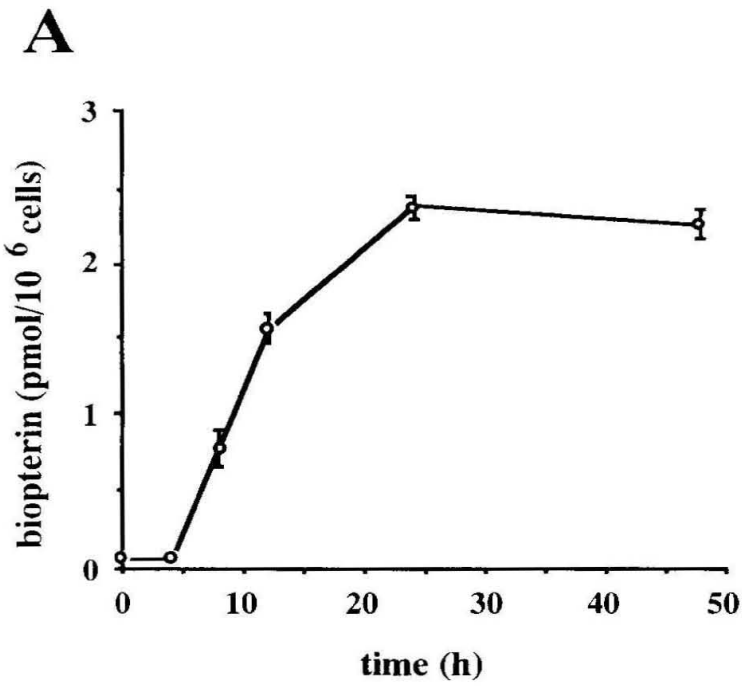

vations. The statistical significance of observed differences was determined by analysis of variance followed by Bonferroni's method. Differences between means were considered significant when $\mathrm{P}$ was less than 0.05 .

\section{Results}

Induction of BH4 synthesis by insulin

We examined whether insulin $(10 \mu \mathrm{g} / \mathrm{ml})$ induces BH4 synthesis in MBMECs. Significant increase in $\mathrm{BH} 4$ content was observed in MBMECs from $8 \mathrm{~h}$ after the addition of insulin (Fig. 1A). The insulininduced increase in of $\mathrm{BH} 4$ content was observed in a concentration-dependent manner (Fig. 1B).

Effects of DAHP and NAS on the synthesis of BH4

To determine whether insulin-induced increase in $\mathrm{BH} 4$ content is due to the de novo synthesis, the effects of DAHP and NAS, both inhibitors of the de novo synthetic pathway of $\mathrm{BH} 4$, were examined. Treatment with DAHP (Fig. 2A), a GTP cyclohydrolase I (GTPCH) inhibitor, or with NAS (Fig. 2B), a sepiapterin reductase inhibitor, inhibited $\mathrm{BH} 4$ synthesis induced by insulin in a concentration-dependent manner.

\section{Discussion}

Addition of insulin to endothelial cells increased intracellular $\mathrm{BH} 4$ content. The biosynthesis of $\mathrm{BH} 4$ can occur via a de novo pathway from GTP to dihy-

B

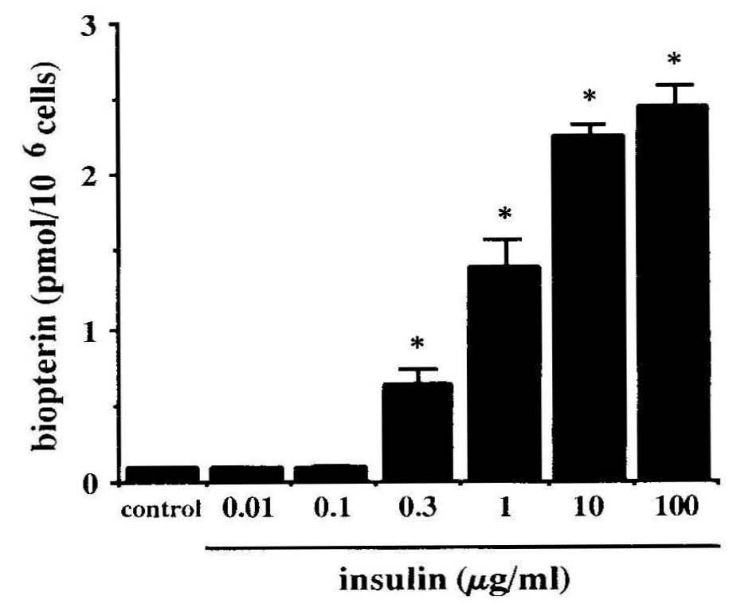

Figure 1. Effect of insulin on intracellular BH4 content in endothelial cells. A; Cells were incubated with insulin (10 $\mu \mathrm{g} / \mathrm{ml})$ for various periods. B; Cells were incubated with insulin $(0.01-100 \mu \mathrm{g} / \mathrm{ml})$ for $24 \mathrm{~h}$. Results are the means IS.E.M. of 10-22 assays. ${ }^{*}$ Significant change in comparison to control group $(\mathrm{p}<0.05)$. 

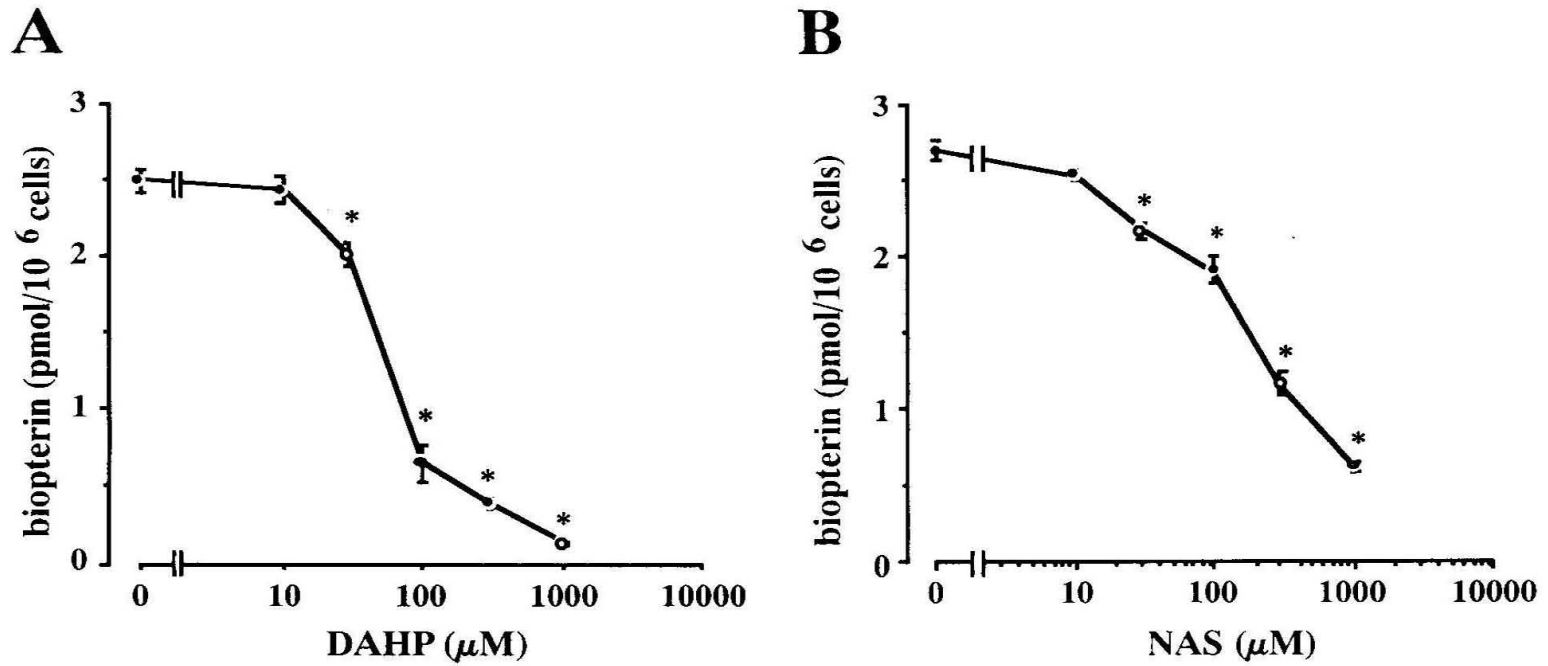

Figure 2. Effects of DAHP and NAS on increase in BH4 content induced by insulin. Cells were incubated with insulin $(10 \mu \mathrm{g} / \mathrm{ml})$ in the absence or presence of DAHP $(10-1000 \mu \mathrm{M}: \mathrm{A})$ or NAS (10-1000 $\mu \mathrm{M}: \mathrm{B})$ for $24 \mathrm{~h}$. Results are the means \pm S.E.M. of 8 -14 assays. ${ }^{*}$ Significant change in comparison to insulin alone group $(\mathrm{p}<0.05)$.

droneopterin triphosphate, in which the enzyme GTPCH catalyzes the first and rate-limiting step. DAHP, a selective inhibitor of GTPCH, inhibited the formation of $\mathrm{BH} 4$ induced by insulin in endothelial cells. Moreover, NAS, an inhibitor of sepiapterin reductase, which converts 6-pyruvoyl tetrahydropterin to BH4, the last step of the de novo pathway of BH4 synthesis, also inhibited the insulininduced increase in $\mathrm{BH} 4$ content. Therefore, insulin may induce the biosynthesis of $\mathrm{BH} 4$ in endothelial cells through the de novo pathway. The mechanisms of BH4 synthesis induced by insulin in MBMECs are needed to examine in further detail in the future.

Insulin has been shown to elicit vasodilation by NO-dependent mechanism in various vessels (1-3). Verma et al. (4) indicated that inhibition of $\mathrm{BH} 4$ synthesis results in an attenuation in the insulininduced vasodilation of rat femoral artery. Therefore, they speculated that insulin may regulate NO production by increasing $\mathrm{BH} 4$ availability for activation of NO synthase. In the present study, we showed that insulin stimulates $\mathrm{BH} 4$ synthesis and increases $\mathrm{BH} 4$ content in endothelial cells. Moreover, we previously reported that the increase in $\mathrm{BH} 4$ content in endothelial cells stimulates calcium ionophore-induced L-citrulline formation, which is a marker for NO production (10). The increase in $\mathrm{BH} 4$ content may be involved in insulin-induced NO production in endothelial cells.

Endothelium-dependent relaxation of aorta by acetylcholine has been known to be decreased in streptozotocin-induced diabetic rats (17-19). Pieper (19) reported that BH4 availability can play a kev role of the regulation of NO production in diabetic endothelial cells, and exogenous $\mathrm{BH} 4$ restores endothelium-dependent relaxation in diabetic rat aorta. Moreover, Hamon et al. (20) suggested that BH4 content in diabetic rat brain is decreased. Under diabetic mellitus, BH4 content of vessels is likely to be decreased. Therefore, it is possible that insulin mav improve endothelium-dependent relaxation by increasing $\mathrm{BH} 4$ content in diabetic rats.

For several vears, we reported that $\mathrm{BH} 4$ has a protective effect against vascular endothelial cell injury induced by $\mathrm{H}_{2} \mathrm{O}_{2}$, NO and a combination of superoxide and $\mathrm{NO}$, which are implicated in a development of reperfusion injury following ischemia (914). More recently, in vivo study, we showed that $\mathrm{BH} 4$ attenuates gastric ischemia-reperfusion injury (15). The protection mechanisms of $\mathrm{BH} 4$ are likely to involve a scavenging activity for reactive oxygen species and antioxidative activity $(10,16)$. Insulin is known to have a protective effect for ischemic injury in various tissues including brain and heart $(7,8)$. It is possible that the increase in $\mathrm{BH} 4$ content induced by insulin may be involved in insulin-induced cell protection. In the future, we will examine whether cell protection mechanisms of insulin against ischemic injury involve increase in $\mathrm{BH} 4$ content.

Recently, we suggested that $\mathrm{BH} 4$ stimulates the proliferation and angiogenesis in bovine endothelial cells (21). Other investigators also showed that BH4 stimulates cell proliferation in various cells including PC12, SV40-transfected human fibroblasts and rat C6 glioma cells (22). Furthermore, growth factors including epidermal growth factor and nerve growth factor are known to increase in synthesis of BH4 $(23,24)$. Insulin is known to stimulate the prolifer- 
ation and angiogenesis in endothelial cells (25). Therefore, it is possible that the increase in $\mathrm{BH} 4$ content in MBMECs may be involved in insulininduced proliferation of MBMECs.

In conclusion, our findings indicate that insulin induces the increase in $\mathrm{BH} 4$ content through a de novo pathway from GTP in MBMECs. The physiological role of increase in $\mathrm{BH} 4$ content induced by insulin will be needed to examine in detail.

\section{References}

1. Scherrer, U, Randin, D, Vollenwcider, P, Vollenweider, L., Nicod, P. Nitric oxide release accounts for insulin's vascular effects in humans. J Clin Invest 1994; 94: 2511-2515.

2. Steinberg, HO, Brechtel, G, Johnson, A, Fineberg, N, Baron AD. Insulin-mediated skeletal muscle vasodilation is nitric oxide dependent: a novel action of insulin to increase nitric oxide relcase. J Clin Invest 1994; 94: 1172-1179.

3. van Veen, S, Chang, PC. Prostaglandins and nitric oxide mediate insulin-induced vasodilation in the human forearm. Cardiovasc Res 1997; 34: 223-229.

4. Verma, S, Arikawa, E, Yao, L, Laher, I, McNeill, JH. Insulin-induced vasodilation is dependent on tetrahydrobiopterin synthesis. Mctabolism 1998; 47: 1037. 1039.

5. Schmidt, K, Werner, ER, Mayer, B, Wachter, H, Kukovetz, WR. Tetrahydrobiopterin-dependent formation of endothelium-derived relaxing factor (nitric oxide) in aortic endothelial cells. Biochem J 1992; 281: 297-300.

6. List, BM, Klösch, B, Völker, C, Gorren, ACF, Sessa, WC, Werner, ER, Kukovetz, WR, Schmidt, K, Mayer, B: Characterization of bovine endothelial nitric oxide synthase as a homodimer with down-regulated uncoupled NADPH oxidase activity: tetrahydrobiopterin binding kinetics and role of haem in dimerization. Biochem J 1997; 323: 159-165.

7. Voll, CL, Auer, RN. Insulin attenuates ischemic brain damage independent of its hypoglycemic effect. J Cereb Blood Flow Metab 1991; 11: 1006-1014.

8. Baines, CP, Wang, L, Cohen, MV, Downey, JM. Myocardial protection by insulin is dependent on phospatidylinositol 3-kinase but not protein kinase C or KATP channels in the isolated rabbit heart. Basic Res Cardiol 1999; 94: 188-198.

9. Ishii, M, Shimizu, S, Yamamoto, T, Momose, K, Kuroiwa, $Y$. Acceleration of oxidative stress-induced endothelial cell death by nitric oxide synthase dysfunction accompanied with decrease in tetrahydrobiopterin content. Life Sci 1997; 61: 739-747.

10. Ishii, M, Shimizu, S, Momose, K, Yamamoto, T. Reduction by tetrahydrobiopterin of $\mathrm{H}_{2} \mathrm{O}_{2}$-induced endothelial cell injury. Pharmacol Toxicol 1998; 82: 280-286.

11. Shimizu, S, Ishii, M, Kawakami, Y, Momose, K, Yamamoto, T. Protective effects of tetrahydrobiopterin against nitric oxide-induced endothelial cell death. Life Sci
1998; 63: 1585-1592.

12. Shimizu, S, Ishii, M, Momose, K, Yamamoto, T. Role of tetrahydrobiopterin in the function of nitric oxide synthase, and its cytoprotective effect (Review). Int J Mol Med 1998; 2: 533-540.

13. Ishii, M, Shimizu, S, Momose, K, Yamamoto, T. SIN1-induced cytotoxicity in cultured endothelial cells involves reactive oxygen species and nitric oxide: protective effect of sepiapterin. J Cardiovasc Pharmacol 1999; 33: 295-300.

14. Ishii, M, Shimizu, S, Momose, K, Kiuchi, Y, Yamamoto, T. Characterization of the protective effect of tetrahydrobiopterin against S-nitroso-N-acetyl-D,L-penicillamine induced endothelial cell injury. Pteridines 1999; 10: 1419.

15. Ishii, M, Shimizu, S, Nawata, S, Kiuchi, Y, Yamamoto, $\mathrm{T}$. Involvement of reactive oxygen species and nitric oxide in gastric ischemia-reperfusion injury in rats : protective effect of tetrahydrobiopterin. Dig Dis Sci in press.

16. Kojima, S, Ona, S, Iizuka, I, Arai, T, Mori, H., Kubota, $\mathrm{K}$. Antioxidative activity of 5,6,7,8-tetrahydrobiopterin and its inhibitory effect on paraquat-induced cell toxicity in cultured rat hepatocytes. Free Radic Res 1995; 23: 419-430.

17. Pieper, GM, Gross, GJ. Oxygen free radicals abolish endothelium-dependent relaxation in diabetic rat aorta. Am J Physiol 1988; 255: H825-H833.

18. Cameron, NE, Cotter, MA. Impaired contraction and relaxation in aorta from streptozotocin-diabetic rats: role of polyol pathway. Diabetologia 1992; 35: 1011-1019.

19. Pieper, GM. Acute amelioration of diabetic endothelial dysfunction with a derivative of the nitric oxide synthase cofactor, tetrahydrobiopterin. J Cardiovasc Pharmacol 1997; 29: 8-15.

20. Hamon, CG, Cutler, P, Blair, JA. Tetrahydrobiopterin metabolism in the streptozotocin induced diabetic state in rats. Clin Chim Acta 1989; 181: 249-254.

21. Shimizu, S, Yasuda, M, Ishii, M, Nagai, T, Kiuchi, Y, Yamamoto, T. Stimulation of in vitro angiogenesis by tetrahydrobiopterin in bovine aortic endothelial cell. Jpn J Pharmacol 1999; 80: 177-180.

22. Anastasiadis, PZ, States, JC, Imerman, BA, Louie, MC, Kuhn, DM, Levine, RA. Mitogenic effects of tetrahydrobiopterin in PC12 cells. Mol Pharmacol 1996; 49: 149-155.

23. Suzuki, H, Nakanishi, N, Yamada, S. Nerve growth factor transiently increases tetrahydrobiopterin and total biopterin contents of pheochromocytoma $\mathrm{PCl} 2 \mathrm{~h}$ cells. Biochem Biophys Res Commun 1988; 153: 382-387.

24. Anastasiadis, PZ, Bezin, L, Imerman, BA, Kuhn, DM, Louie, MC, Levine, RA. Tetrahydrobiopterin as a mediator of $\mathrm{PCl} 2$ cell proliferation induced by EGF and NGF. Eur J Neurosci 1997; 9: 1831-1837.

25. Hayashi, JN, Ito, H, Kanayasu, T, Morita, I, Murota, $S$. Stimulatory effects of insulin and insulin-like growth factor I on migration and tube formation by vascular endothelial cells. Atherosclerosis 1992; 92: 141-149. 